\title{
Proses Pembentukan Peraturan Daerah Kabupaten Muna Sulawesi Tenggara
}

\author{
Muhammad Asrianto Zainal \\ Fakultas Syari’ah Institut Agama Islam Negeri Kendari \\ asrianto.1zainal@gmail.com
}

\begin{abstract}
Abstrcat
This study will discuss the process of establishing the regional regulations of Muna regency, especially the constraints. The results indicate that the establishment of regional regulations of Muna is based on DPRD Regulation Number 1/DPRD/2014 concerning the Rules of Procedure for the Muna Regency, which DPRD begins with the planning, drafting, discussion, stipulation, enactment, dissemination and evaluation of regional regulations. The formation of regulations in Muna Regency only follows procedural stages but is not substantially regulated regarding the necessity of academic manuscripts and community participation and not in accordance with Law Number 12 of 2011 concerning the Establishment of Laws and Regulations of the Minister of Home Affairs Number 1 of 2014 in legal substance, structure, and culture, such as it is not clearly regulated the necessity of making academic texts; lack of human resources; lack of community participation, universities and other parties in the process of establishing regional regulations.
\end{abstract}

\section{Keywords: academic manuscript; regional regulation; regional house of representative; rules of procedures}

\begin{abstract}
Abstrak
Studi ini akan membahas proses pembentukan Peraturan Daerah Di Kabupaten Muna, kendala-kendala yang dihadapi, dan solusi dalam pembentukan peraturan daerah. Hasil penelitian menunjukkan bahwa pembentukan Peraturan Daerah di Kabupaten Muna berdasarkan Peraturan DPRD Nomor 1/DPRD/2014 Tentang Tata Tertib DPRD Kabupaten Muna diawali dari tahap perencanaan, penyusunan, pembahasan, penetapan, pengundangan, sosialisasi dan evaluasi peraturan daerah. Dalam prakteknya pembentukan peraturan di Kabupaten Muna hanya mengikuti tahapan prosedural saja tetapi tidak secara substansi diatur mengenai keharusan naskah akademik dan adanya partisipasi masyarakat. Hal tersebut tidak bersesuaian dengan UU Nomor 12 Tahun 2011 Tentang Pembentukan Peraturan Perundang-Undangan dan Peraturan Menteri Dalam Negeri Nomor 1 Tahun 2014 tentang Pembentukan Produk Hukum Daerah. Dari aspek substansi hukum, kendalanya adalah tidak diaturnya secara jelas keharusan membuat naskah akademik dalam Peraturan DPRD Nomor 1/DPRD/2014; dari aspek struktur hukum, kurangnya sumber daya manusia dari pihak DPRD; dari aspek budaya hukum, kurangnya partisipasi masyarakat, perguruan tinggi serta pihak lain dalam proses pembentukan peraturan daerah. Solusi yang diperlukan yaitu adanya pelatihan kepada para perancang peraturan daerah baik dari pihak DPRD maupun dari pemerintah daerah, pengkajian ulang terhadap Peraturan DPRD Nomor 1/DPRD/2014 dan dibukanya ruang partisipasi aktif masyarakat.
\end{abstract}

Kata Kunci: Dewan Perwakilan Rakyat Daerah; naskah akademik; peraturan daerah; prosedur hukum

\section{A. Pendahuluan}

Hubungan pemerintah pusat dan pemerintah daerah, dalam sejarah ketatanegaraan Republik Indonesia senantiasa memiliki daya tarik tersendiri untuk dikaji. Hal ini membuktikan 
bahwa masalah hubungan antara pusat dan daerah dapat menjamin tegaknya Negara Kesatuan Republik Indonesia sebagaimana yang diamanatkan oleh Undang-Undang Dasar $1945^{1}$.

Dalam perkembangan sejak kemerdekaan sampai dengan periode demokrasi terpimpin, tergambar bagaimana tantangan yang dihadapi oleh gagasan otonomi daerah dan prinsip desentralisasi yang luas. Puncak dari sistem sentralisasi di masa Orde Lama ialah pada era Demokrasi Terpimpin itu yaitu dengan terjadinya pemberontakan G.30.S/PKI pada tahun 1965. Setelah terjadinya pergantian presiden pada tahun 1967, barulah muncul kembali apresiasi mengenai pentingnya prinsip otonomi daerah dan desentralisasi pemerintahan. Hal ini terlihat jelas dalam TAP MPRS tanggal 5 Juli 1966, No. XXI/MPRS/1966 Tentang Pemberian otonomi yang seluas-luasnya kepada daerah ${ }^{2}$.

Setelah memasuki masa reformasi pada tahun 1998 yang juga ditandai dengan penggantian kekuasaan dari Presiden Soeharto ke Presiden B.J. Habibie, aspirasi mengenai otonomi daerah dan desentralisasi muncul kembali. Dalam sidang MPR tahun 1998, kebijakan desentralisasi itu dituangkan dengan jelas dalam ketetapan MPR berisi ketentuan tentang penyelenggaraan otonomi daerah, pengaturan, pembagian, pemanfaatan sumber daya nasional yang berkeadilan, serta perimbangan keuangan antara pusat dan daerah dalam kerangka Negara Kesatuan Republik Indonesia. Untuk melaksanakan ketetapan MPR ini, atas inisiatif pemerintah telah disahkan Undang-Undang Nomor 22 tahun 1999 tentang Pemerintahan Daerah dan Undang-Undang dan Undang-Undang Nomor 25 Tahun 1999 Tentang Perimbangan Keuangan Antara Pemerintah Pusat dan Daerah. Semangat yang melandasi pengesahan kedua undang-undang itu sangat tinggi sehingga dalam sidang tahunan MPR tahun 2000 sekali lagi ditetapkan ketetapan MPR yang merekomendasikan kebijakan-kebijakan operasional dalam rangka pelaksanaan otonomi daerah itu. Ketetapan MPR tersebut adalah TAP No. IV/MPR/2000 tentang Rekomendasi kebijakan dalam penyelenggaraan otonomi daerah $^{3}$.

Sistem pemerintahan daerah begitu dekat hubungannya dengan otonomi daerah yang saat ini telah diterapkan di Indonesia. Jika sebelumnya semua sistem pemerintahan bersifat terpusat atau sentralisasi maka setelah diterapkannya otonomi daerah diharapkan daerah bisa mengatur kehidupan pemerintahan daerah sendiri dengan cara mengoptimalkan potensi daerah yang ada. Meskipun beberapa hal tetap harus diatur oleh pemerintah pusat. Sistem pemerintahan daerah juga sebetulnya merupakan salah satu wujud penyelenggaraan pemerintahan yang efisien dan efektif. Sebab pada umumnya tidak mungkin pemerintah pusat mengurusi semua permasalahan negara yang begitu kompleks.

Menurut pasal 57 UU Nomor 23 Tahun 2014 tentang Pemerintahan daerah bahwa penyelenggaraan pemerintahan daerah adalah pemerintah daerah dan DPRD. Dalam hal ini pemerintah daerah adalah Gubernur, Bupati dan Walikota dan perangkat daerah sebagai unsur penyelenggara pemerintahan daerah. Sedangkan Dewan Perwakilan Rakyat Daerah (DPRD) adalah lembaga perwakilan rakyat daerah sebagai unsur penyelenggara pemerintahan daerah. Dalam menyelenggarakan pemerintahan daerah, pemerintah daerah menggunakan asas otonomi dan tugas pembantuan. Dalam penyelenggaraan pemerintahan daerah, daerah harus mengatur dan mengurus rumah tangganya sendiri, yakni salah satunya mengenai pembentukan peraturan daerah sebagai landasan hukum di daerah yang tidak bertentangan dengan peraturan perundang-undangan yang lebih tinggi dan/atau kepentingan umum.

Dalam kenyataan di Kabupaten Muna saat ini, prosedur atau tata cara kerja dalam pembentukan peraturan daerah sepertinya bukan lagi menjadi unsur penting yang menjadi titik

\footnotetext{
${ }^{1}$ Muhammad Fauzan, Hukum Pemerintahan Daerah Kajian Tentang Hubungan Keuangan Antara Pusat dan Daerah, (Yogyakarta: UII Press, 2006), h. 1.

2 Jimly Asshiddiqie, Konstitusi dan Konstitualisme Indonesia, (Jakarta: Konstitusi Press, 2006), h. 206.

${ }^{3}$ Ni'matul Huda, Hukum Pemerintahan Daerah, (Bandung: Nusa Media, 2009), h. 92.
} 
perhatian pemerintah daerah dan DPRD. Prosedur yang dilakukan tidak didasarkan pada naskah akademik, tidak melalui proses diskusi publik serta tidak disosialisasikan secara efektif. Oleh karenanya, materi dan muatan peraturan daerah yang dihasilkan tidak membawa hasil yang bermanfaat bagi kehidupan masyarakat luas. Padahal jika dipandang berdasarkan sudut pandang hukum, jika peraturan daerah dibuat dengan mengikuti tahapan baku pembentukan peraturan perundang-undangan sebagaimana yang diamanatkan oleh Undang-Undang Nomor 12 Tahun 2011, maka peraturan daerah tersebut akan mampu menjawab segala kebutuhan hukum masyarakat.

Penelitian-penelitian tentang pembentukan peraturan daerah di Indonesia sudah banyak dilakukan, diantaranya adalah penelitian Ibrahim yang menyorot Interaksi Politik Dan Hukum Dalam Proses Pembentukan Peraturan Daerah Di Jawa Timur. ${ }^{4}$ Penelitian lain dilakukan oleh Chandraningrum yang menyoal tentang Perda Syari'ah dalam perspektif kritik perempuan Indonesia. ${ }^{5}$ Penelitian yang menyasar efektivitas Perda dilakukan oleh Ratu di Kabupaten Sleman tentang Implementasi Perda No. 6 Tahun 2015 Tentang Perparkiran Di Kabupaten ini. ${ }^{6}$ Begitu pula halnya yang dilakukan Marpaung tentang Implementasi Peraturan Daerah Kabupaten Labuhanbatu Nomor 37 Tahun 2008 Tentang Pembentukan Organisasi Dan Tata Kerja Kecamatan. ${ }^{7}$ Penelitian-penelitian tersebut menyoroti pembentukan Perda di wilayah Jawa Timur dan beberapa menfokuskan pada implementasi dan efektivitas Perda sebagaimana yang dilakukan Marpaung dan Rudi. Penelitian Chandraningrum lebih menghkususkan pada Perda Syari'ah dalam perspektif perempuan. Penelitian ini akan menyoroti proses pembentukan Perda di kabupaten Muna, salah satu kabupaten di wilayah Sulawesi Tenggara untuk menguji apakah sudah memenuhi unsur-unsur pemenuhan prosedur hukum normatif. Dengan menggunakan pendekatan hukum normatif, penelitian ini diarahkan pada proses pembentukan Peraturan Daerah di Kabupaten Muna serta kendala yang dihadapi dalam proses pembentukan Peraturan Daerah tersebut.

\section{B. Proses Pembentukan Peraturan Daerah di Kabupaten Muna}

Dalam penyelenggaran otonomi daerah, ada 2 (dua) produk hukum yang dapat dibuat oleh suatu daerah, salah satunya adalah peraturan daerah. Kewenangan membuat peraturan daerah (Perda), merupakan wujud nyata pelaksanaan hak otonomi yang dimiliki oleh suatu daerah dan sebaliknya peraturan daerah merupakan salah satu sarana dalam penyelenggaraan otonomi daerah. Perda ditetapkan oleh Kepala Daerah setelah mendapat persetujuan bersama $\mathrm{DPRD}^{8}$, untuk penyelenggaraan otonomi yang dimiliki oleh provinsi dan kabupaten/kota, serta tugas pembantuan. Perda pada dasarnya merupakan penjabaran lebih lanjut dari peraturan perundang-undangan yang lebih tinggi, dengan memperhatikan ciri khas masing-masing daerah. Perda yang dibuat oleh suatu daerah tidak boleh bertentangan dengan kepentingan

\footnotetext{
${ }^{4}$ Anis Ibrahim, “Legislasi dalam Perspektif Demokrasi: Analisis Interaksi Politik Dan Hukum Dalam Proses Pembentukan Peraturan Daerah Di Jawa Timur”, Disertasi di Uniersitas Diponegoro Semarang, 2008.

5 Dewi Chandraningrum, "Perda Sharia and the Indonesian Women's Critical Perspectives', Paper presented to Perda Syariah (New Arbitrary against Women in Indonesia: Perda Sharia and Women's Right, Bremen, Germany, 11 November 2006.

${ }^{6}$ Frederick Afridus Ratu dan Argo Pambudi, Implementasi Perda No. 6 Tahun 2015 Tentang Perparkiran Di Kabupaten Sleman, (Yogyakarta: Universitas Negeri Yogyakarta, 2016)

${ }^{7}$ Heri Wahyudi Marpaung, "Implementasi Peraturan Daerah Kabupaten Labuhanbatu Nomor 37 Tahun 2008 Tentang Pembentukan Organisasi Dan Tata Kerja Kecamatan”, Jurnal Administrasi Publik, Vol. 1, No. 1, Juni 2011: 29-50.

${ }^{8}$ Lihat Pasal 236 Ayat (2) UU. Nomor 23 Tahun 2014 Tentang Pemerintahan Daerah.
} 
umum dan/atau peraturan perundang-undangan yang lebih tinggi ${ }^{9}$ dan baru mempunyai kekuatan mengikat setelah diundangkan dengan dimuat dalam lembaran daerah.

Peraturan Daerah memiliki beberapa fungsi ${ }^{10}$, yaitu:

a. Menyelenggarakan pengaturan dalam rangka penyelenggaraan otonomi daerah dan tugas pembantuan.

b. Menyelenggarakan pengaturan sebagai penjabaran lebih lanjut peraturan perundangundangan yang lebih tinggi dengan memperhatikan ciri khas masing-masing daerah.

c. Menyelenggarakan pengaturan hal-hal yang tidak bertentangan dengan kepentingan umum.

d. Menyelenggarakan pengaturan hal-hal yang tidak bertentangan dengan peraturan perundang-undangan yang lebih tinggi. Yang dimaksud disini adalah tidak bertentangan peraturan perundang-undangan di tingkat pusat.

Dalam perkembangannya peraturan daerah mengalami perubahan dalam pembentukannya. Di daerah dibentuk adanya DPRD sebagai badan legislative daerah dan pemerintah daerah sebagai eksekutif daerah. Pada masa orde baru dalam hal pembentukan peraturan daerah didominasi oleh eksekutif daerah atau pemerintah daerah. Namun dalam era reformasi ini baik eksekutif maupun legislatif daerah mempunyai keseimbangan dalam hal pembentukan peraturan daerah. Dalam UU nomor 12 tahun 2011 tentang Pembentukan Peraturan Perundang-undangan, ada dua macam peraturan daerah yaitu peraturan daerah provinsi dan peraturan daerah kabupaten/kota. Pasal 1 ayat 7 menegaskan bahwa:

"Peraturan Daerah provinsi adalah peraturan perundang-undangan yang dibentuk oleh Dewan Perwakilan Rakyat Daerah Provinsi dengan persetujuan bersama Gubernur".

Dalam Pasal 1 ayat 8 menegaskan pula bahwa:

"Peraturan Daerah Kabupaten/Kota adalah peraturan perundang-undangan yang dibentuk oleh Dewan Perwakilan Rakyat Daerah Kabupaten/Kota dengan persetujuan bersama Bupati/Walikota".

Dalam hal materi muatan yang harus diatur dalam pembentukan peraturan daerah, Pasal 14 menentukan bahwa:

"Materi muatan peraturan daerah provinsi dan peraturan daerah kabupaten/kota berisi materi muatan dalam rangka penyelenggaraan otonomi daerah dan tugas pembantuan serta menampung kondisi khusus daerah dan/ atau penjabaran lebih lanjut peraturan perundang-undangan yang lebih tinggi”.

Dalam pembentukan Peraturan Daerah di Kabupaten Muna mengacu kepada ketentuan Peraturan Dewan Perwakilan Rakyat Daerah (DPRD) Kabupaten Muna Nomor 1/DPRD/2014 tentang Tata Tertib (Tatib) Dewan Perwakilan Rakyat Daerah (DPRD) Kabupaten Muna. Tahapan pembentukan Peraturan Daerah Kabupaten Muna berdasarkan Peraturan DPRD Nomor 1/DPRD/2014 Kabupaten Muna tentang Tata tertib DPRD Kabupaten Muna adalah sebagai berikut:

a. Tahap perencanaan Peraturan Daerah

Tahap pertama pembentukan Peraturan Daerah baik Provinsi maupun Kabupaten/Kota pada dasarnya adalah sama yakni diawali dengan tahap perencanaan yang dituangkan dalam bentuk program legislasi daerah. Program legislasi daerah (Prolegda) adalah instrument

\footnotetext{
${ }^{9}$ Lihat Penjelasan Pasal 236 ayat (2) huruh b UU Nomor 23 Tahun 2014.

${ }^{10}$ Ibid. h. 93.
} 
perencanaan pembentukan peraturan daerah yang disusun secara berencana, terpadu dan sistematis. $^{11}$

Setelah penyusunan program legislasi daerah dilakukan, program legislasi daerah kemudian disebarluaskan oleh DPRD bersama sama dengan pemerintah daerah untuk diketahui oleh masyarakat luas sebagai bahan pertimbangan untuk memperoleh masukan dari masyarakat. Namun demikian, wawancara dengan Wakil Ketua Badan Legislasi Kabupaten Muna $^{12}$ menunjukan bahwa prosedur ini belum dijalankan secara maksimal dan efektif dengan melibatkan partisipasi masyarakat luas. Prosedur ini semestinya adalah proses dimana pihak DPRD dan pemerintah daerah tidak menyebarluaskan lebih dulu ke masyarakat tentang program legislasi daerah yang telah disusun oleh pihak DPRD bersama dengan pemerintah daerah sebelum mendapatkan masukan dar masyarakat.

Dalam pembentukan Peraturan Daerah, Rancangan Peraturan Daerah dapat berasal dari Dewan Perwakilan Rakyat Daerah (DPRD) maupun Bupati yang harus disertai dengan penjelasan atau naskah akademik terkait dengan Rancangan Peraturan Daerah yang diajukan dan didasarkan pada skala prioritas program legislasi daerah yang sudah disetujui bersama antara Dewan Perwakilan Rakyat Daerah dan Bupati. Ketentuan mengenai Rancangan Peraturan Daerah ini terdapat dalam pasal 110 dan 111 Peraturan DPRD Kabupaten Muna Nomor 1/DPRD/2014 Tentang Tatib DPRD Kabupaten Muna.

Dalam prakteknya, rancangan Peraturan Daerah yang berasal dari pemerintah daerah atau usul prakarsa dari SKPD dan Rancangan peraturan daerah atas usul DPRD tidak dijalankan sebagaimana tahapan dalam perencanaan adanya suatu rancangan perda. Berdasarkan wawancara penulis dengan Sekretaris Dewan ${ }^{13}$ bahwa dalam merencanakan suatu rancangan Perda, pihak SKPD yang mewakili pemerintah daerah dan DPRD tidak memiliki naskah akademik, semnatara pembuatan naskah akademik adalah salah saltu tahap yang harus dilalui dalam pembentukan Peraturan daerah. ${ }^{14}$ Hanya satu Perda yang memiliki naskah akademik, yaitu Perda tentang Perlindungan Perempuan dan Anak Korban Kekerasan. Hal ini berdampak pada peraturan daerah yang dihasilkan tersebut kurang berpihak pada masyarakat luas sekaligus kurang menjawab kebutuhan hukum masyarakat di Kabupaten Muna. Semestinya keterlibatan masyarakat (public participation) sangat diperlukan dalam proses pengambilan keputusan (decision-making process), terutama diera otonomi daerah. ${ }^{15}$ Sebagaimana tertuang dalam Pasal 96 Undang-Undang Republik Indonesia Nomor 12 Tahun 2011 tentang Pembentukan Peraturan Perundang-Undangan disebutkan secara tegas bahwa masyarakat berhak memberikan masukan secara lisan atau tertulis dalam pembentukaan peraturan perundangundangan yang dapat dilakukan melalui rapat dengar pendapat umum, kunjungan kerja, sosialisasi dan/atau, seminar, lokakarya dan/atau diskusi. Namun tidak demikian halnya di Kabupaten Muna dimana peraturan-peraturan daerah yang dihasilkan tidak melalui proses pengkajian dan penelitian lebih dahulu.

b. Tahap Pembahasan Rancangan Peraturan Daerah

11 Sunarno Danusastro, Penyusunan Program Legislasi Daerah yang Partisipatif, Jurnal Konstitusi, Volume 9, Nomor 4, Desember 2012: 642-660.

${ }^{12}$ Hasil wawancara dengan Iskandar, S. Sos., selaku Wakil Ketua Badan Legislasi Kabupaten Muna di Kantor DPRD Kabupaten Muna pada tanggal 3 Juli 2017.

${ }^{13}$ Hasil wawancara dengan Plt Sekretaris dewan selaku Kepala Bagian Hukum Kab. Muna di Kantor DPRD Kaupaten Muna pada tanggal 4 Juli 2017

14 Bambang Setyadi, "Pembentukan Peraturan Daerah", Buletin Hukum Perbankan Dan Kebanksentralan, Volume 5, Nomor 2, Agustus 2007: 1-17.

${ }^{15}$ Tomy M Saragih, "Konsep Partisipasi Masyarakat dalam Pembentukan Peraturan Daerah Rencana Detail Tata Ruang dan Kawasan”, Jurnal Sasi Vol. 17 No. 3 Bulan Juli-September 2011: 11-20. 
Dalam proses pembahasan Peraturan Daerah di DPRD Kabupaten Muna yang dilakukan oleh DPRD dan Bupati atau yang mewakilinya, tidak berlangsung secara mendalam dan bersifat substansial. Proses yang dilalui untuk menghasilkan produk hukum berupa peraturan daerah terjadi proses yang panjang dan alot, tetapi hanya bersifat seremonial dan prosedural semata. Dalam proses pembahasan tersebut lebih kepada menjalani tahapan dalam rapat paripurna dibandingkan dengan penjelasan-penjelasan yang sangat substansi dan mendasar. Meskipun terjadi perdebatan, tetapi hanya mengikuti tahapan dalam rapat paripurna, sehingga Perda yang dihasilkan pun tidak mencerminkan dan dapat menjawab kebutuhan hukum masyarakat yang menjadi inti atau pokok dari adanya suatu rancangan Perda. Di samping itu, dipengaruhi pula oleh kualiatas dari anggota DPRD itu sendiri yang tidak mempunyai latar belakang dan pendidikan yang mumpuni sehingga dalam rapat paripurna proses pembahasan Perda kurang dapat mengambil peran yang cukup signifikan dalam menyalurkan aspirasi masyarakat dan dapat menjawab kebutuhan hukum masyarakat. Kondisi ini dikuatkan oleh Ketua DPRD Kabupaten Muna $^{16}$ yang menyatakan bahwa kualitas sumber daya manusia (SDM) para Anggota Dewan di Muna sangat minim, sehingga mengakibatkan dalam proses pembahasan suatu peraturan daerah hanya pimpinan fraksi dan pimpinan komisi saja yang aktif. Selain itu hanya satu atau dua orang di Badan Legislasi yang aktif dalam proses pembahasan suatu rancangan peraturan daerah.

Selain kondisi di atas, pembahasan Peraturan Daerah di DPRD Kabupaten Muna juga kurang melibatkan partisipasi masyarakat. Hal ini diakibatkan oleh masyarakat itu sendiri yang kurang memahami terkait dengan proses pembahasan dan jadwal di DPRD terkait dengan pembahasan suatu rancangan Peraturan Daerah. Ataupun masyarakat dilibatkan, akan tetapi yang dihadirkan adalah orang-orang yang dekat dengan birokrasi dan/atau kekuasaan. Sehingga hanya segelintir orang-orang yang terlibat dalam proses penysunan dan itupun berkepentingan secara praktis dan pragmatis terhadap Perda yang sedang disusun. Partisipasi dan keterlibatan masyarakat sesungguhnya dapat mengurangi kemungkinan terjadinya konflik dalam menerapkan suatu keputusan, sekaligus mendukung penerapan akuntabilitas, serta pengawasan publik terhadap kebijakan pemerintah. ${ }^{17}$ Tidak dilibatkannya masyarakat tersebut diakibatkan pula oleh tempat domisili masyarakat Kabupaten Muna pada umumnya terdiri atas beberapa pulau dan kecamatan yang jaraknya cukup jauh dengan tempat ibukota kabupaten dimana tempat pembahasan terhadap suatu rancangan Peraturan Daerah itu dibahas antara DPRD bersama dengan pemerintah daerah dalam hal ini Bupati. Hal ini dapat terjadi pula akibat kurangnya sosialisasi baik dari anggota maupun kelembagaan DPRD itu sendiri baik melalui media massa, radio, seminar, dan lain sebagainya maupun dari pemerintah daerah. Akibatnya, masyarakat tidak mengetahui akan adanya pembahasan suatu rancangan peraturan daerah di DPRD Kabupaten Muna antara DPRD bersama dengan pemerintah daerah.

c. Tahap penetapan dan pengundangan Peraturan Daerah

Rancangan peraturan daerah menjadi Peraturan Daerah setelah disetujui bersama oleh DPRD dan Bupati kemudian ditetapkan oleh Bupati. Penetapan rancangan Peraturan Daerah menjadi Peraturan Daerah didahului dengan penyampaian oleh Pimpinan Dewan Perwakilan Rakyat Daerah kepada Bupati dalam jangka waktu paling lambat 7 (tujuh) hari terhitung sejak tanggal persetujuan bersama. Ketentuan ini terdapat dalam pasal 116 Peraturan DPRD Kabupaten Muna Nomor 1/DPRD/2014 tentang Tatib DPRD Kabupaten Muna. 4 Juli 2017

${ }^{16}$ Hasil wawancara dengan Mukmin Naini, S. Ag., selaku Ketua DPRD Muna di Kantor DPRD Muna pada tanggal

${ }^{17}$ Kemilau Mutik, "Kedudukan Naskah Akademik dalam Proses Pembentukan Peraturan Daerah", Tesis di Fakultas Hukum Universitas Brawijaya, Malang, 2010, hlm. 27 
Penetapan rancangan Peraturan Daerah menjadi Peraturan Daerah oleh Bupati dilakukan dengan membubuhkan tanda tangan paling lambat 30 (tiga puluh) hari terhitung sejak rancangan Peraturan Daerah tersebut disetujui bersama oleh Dewan Perwakilan Rakyat Daerah dan Kepala Daerah. Apabila dalam jangka waktu 30 (tiga puluh) hari terhitung sejak tanggal persetujuan bersama oleh Dewan Perwakilan Rakyat Daerah dan Kepala Daerah, Kepala Daerah tidak menandatangani rancangan Peraturan Daerah yang telah disetujui bersama, maka rancangan Peraturan Daerah tersebut sah menjadi Peraturan Daerah dan wajib diundangkan dalam lembaran daerah yang pengesahannya berbunyi "Peraturan Daerah ini dinyatakan sah". Kalimat ini dibubuhkan pada halaman terakhir Peraturan Daerah sebelum pengundangan naskah peraturan daerah ke dalam lembaran daerah dan berlaku setelah diundangkan dalam lembaran daerah. Dalam hal penetapan, pengesahan dan pengundangan rancangan Peraturan Daerah menjadi peraturan daerah diatur dalam pasal 117 Peraturan DPRD Nomor 1/DPRD/2014 tentang Tata tertib DPRD Kabupaten Muna.

Peraturan daerah yang telah ditetapkan selanjutnya ditempatkan dalam lembaran daerah, yang dimaksudkan sebagai syarat hukum agar setiap orang mengetahuinya. Lembaran daerah adalah penerbitan resmi yang digunakan untuk mengundangkan peraturan daerah dan keputusan Kepala Daerah sedangkan Berita Daerah adalah penerbitan resmi pemerintah daerah yang digunakan untuk mengumumkan Peraturan Daerah, Keputusan Kepala Daerah. Dalam prakteknya di Kabupaten Muna, pada tahap penetapan dan pengundangan ini telah berjalan sebagaimana mestinya yang telah diatur dalam Peraturan DPRD Kabupaten Muna Nomor 1/DPRD/2014 Tentang Tata Tertib DPRD Kabupaten Muna.

\section{d. Tahap sosialisasi Peraturan Daerah}

Peraturan daerah setelah diundangkan dalam lembaran daerah belum cukup menjadi alasan untuk menganggap bahwa masyarakat telah mengetahui eksistensi peraturan daerah tersebut. Oleh karena itu, Peraturan Daerah yang telah disahkan dan diundangkan tersebut harus pula disosialisasikan. Peraturan daerah Kabupaten Muna yang telah diundangkan dalam lembaran daerah dilakukan bersama oleh DPRD dan pemerintah daerah Kabupaten Muna. Metode sosialisasi dapat dilakukan dengan beberapa cara baik itu melalui berita daerah (RRI, TV daerah). Sosialisasi secara langsung kepada masyarakat melalui seminar dan lokakarya (Semiloka) atau pun Sosialisasi melalui sarana internet.

Dalam prakteknya di Kabupaten Muna, sosialisasi Peraturan Daerah yang telah diundangkan dalam lembaran daerah yang dilakukan DPRD Kabupaten Muna melalui seminar, sosialisasi secara langsung atau pun melalui berita daerah tidak dilakukan secara maksimal. Satu-satunya sosialisasi yang dilakukan kepada masyarakat adalah melalui seminar. Hal ini sangat berpengaruh pada tingkat pengetahuan dan kesadaran masyarakat terkait adanya suatu Peraturan Daerah. Hal lain yang dapat dilihat bahwa tidak diaturnya secara jelas dan terperinci atau dimuatnya sosialisasi dalam Tatib DPRD Kabupaten Muna mengakibatkan para pihak terkait, baik dari DPRD maupun pemerintah daerah tidak aktif dalam melakukan sosialisasi Peraturan Daerah yang telah ditetapkan dan diundangkan. Hal tersebut mengakibatkan banyak masyarakat yang tidak mengetahui adanya suatu Peraturan Daerah yang telah diundangkan tersebut.

\section{e. Tahap Evaluasi Peraturan Daerah}

Untuk dapat mengetahui sejauh mana pengaruh suatu Peraturan Daerah setelah diberlakukan maka perlu dilakukan evaluasi. Melalui evaluasi maka akan dapat diketahui kelemahan dan kelebihan Peraturan Daerah yang sedang diberlakukan yang selanjutnya dapat dijadikan tolak ukur guna menentukan kebijakan terkait dengan adanya suatu Peraturan Daerah tersebut apakah tetap diberlakukan atau perlu adanya perbaikan atau perubahan. Pada tahap 
evaluasi ini harus melibatkan beberapa elemen di dalam DPRD itu sendiri maupun dari pemerintah daerah. Evaluasi ini bertujuan agar setiap Peraturan Daerah yang telah ditetapkan dan diundangkan tersebut dapat dilihat efektifitasnya di tengah-tengah masyarakat.

Mengenai evaluasi peraturan daerah di Kabupaten Muna belum dilakukan secara maksimal oleh DPRD bersama dengan pemerintah daerah. Hal tersebut dikarenakan oleh ketidakaktifan baik dari pihak DPRD maupun pemerintah daerah untuk melakukan evaluasi langsung di lapangan atau masyarakat terkait dengan adanya Peraturan Daerah yang telah ditetapkan dan diundangkan. Sehingga masyarakat secara luas pun juga tidak mengetahui tentang adanya Peraturan Daerah yang telah di undangkan, kecuali masyarakat yang terlibat langsung dengan adanya atau terbitnya Peraturan Daerah tersebut misalnya terkait izin maupun pajak daerah dan retribusi daerah.

\section{Uji Materi atas Produk Hukum Perda Kabupaten Muna}

Peraturan DPRD Nomor 1/DPRD/2014 tentang Tata tertib DPRD Kabupaten Muna merupakan peraturan yang pembuatannya diperintahkan Undang-Undang dan penyusunannya berpedoman pada peraturan perundang-undangan yang lebih tinggi. Dengan demikian, maka ketentuan-ketentuan dalam Peraturan DPRD tentang Tatib ini tidak boleh bertentangan dengan peraturan perundang-undangan yang lebih tinggi pula. Namun dari hasil pengamatan diperoleh bahwa bahwa peraturan DPRD Kabupaten Muna Nomor 1/DPRD/2014 tentang Tatib DPRD Kabupaten Muna sudah tidak sesuai lagi dengan peraturan yang lebih tinggi. Hal ini bisa dilihat dari setelah diundangkannya UU Nomor 12 Tahun 2011 dan Permendagri Nomor 1 tahun 2014 yang mengganti Permendagri Nomor 53 Tahun 2011 sebelumnya sehingga perlu adanya pengkajian ulang dan harus diganti dengan peraturan yang baru agar tidak bertentangan dengan peraturan perundang-undangan yang lebih tinggi.

Dalam peraturan DPRD Kabupaten Muna Nomor 1/DPRD/2014 tentang Tata Tertib DPRD Kabupaten Muna tidak memuat secara tegas dan jelas mengatur tentang rancangan Peraturan Daerah yang diajukan berdasarkan Prolegda. Dalam pasal 110 ayat 3 Peraturan DPRD Nomor 1/DPRD/2014 tentang Tatib DPRD tersebut hanya menjelaskan bahwa "Rancangan Peraturan Daerah disusun berdasarkan program legislasi daerah" tanpa mengatur secara rinci materi-materi yang dimasukkan dalam Prolegda dan pentingnya Prolegda. Hal ini berarti bahwa Peraturan DPRD Nomor 1/DPRD/2014 tentang Tatib DPRD tersebut belum sepenuhnya bersesuaian dengan peraturan perundang-undangan yang lebih tinggi yakni UU Nomor 12 Tahun 2011 dan Permendagri Nomor 1 Tahun 2014. Dalam UU Nomor 12 Tahun 2011 yang mengatur tentang pentingnya prolegda dan secara jelas diatur dalam UU ini terkait dengan prolegda. Hal ini dapat dilihat dari pasal 32 UU Nomor 12 Tahun 2011 tentang Pembentukan Peraturan Perundang-undangan yang mengatur tentang pentingnya perencanaan penyusunan Peraturan Daerah dilakukan dalam Prolegda. Selain itu diatur pula dalam pasal 33 UU Nomor 12 Tahun 2011 tentang Pembentukan Peraturan Perundang-undangan dimana diatur pula materi dalam Prolegda dan keterkaitannya dengan peraturan perundang-undangan lainnya. Selanjutnya dalam Permendagri Nomor 1 Tahun 2014 tentang Pembentukan Produk Hukum Daerah juga diatur secara jelas terkait dengan Prolegda. Hal ini dapat dilihat dalam pasal 9, pasal 10, pasal 11, pasal 12, pasal 13, pasal 14, pasal 15 Permendagri Nomor 1 tahun 2014 tentang Pembentukan Produk Hukum Daerah.

Dalam peraturan DPRD Kabupaten Muna Nomor 1/DPRD/2014 tentang Tatib DPRD Kabupaten Muna juga tidak mengatur secara jelas ke dalam pasal-pasal, terkait dengan adanya naskah akademik. Dalam hal ini pasal-pasal yang dimuat dalam Peraturan DPRD Nomor 1/DPRD/2014 tentang Tatib DPRD tersebut tidak mewajibkan kepada para perancang atau pemrakarsa untuk melakukan suatu penelitian dan dituangkan dalam naskah akademik, tidak pula diwajibkan bahwa rancangan perda harus memiliki naskah akademik. Dalam pasal 110 
ayat (2) Peraturan DPRD Nomor 1/DPRD/2014 Tentang Tatib DPRD Kabupaten Muna hanya disebutkan bahwa "Rancangan peraturan daerah dapat berasal dari DPRD atau Bupati disertai penjelasan atau keterangan dan/atau naskah akademis".

Dari pasal tersebut diatas menunjukkan bahwa naskah akademik hanya diatur dalam 1 (satu) pasal. Hal tersebut menunjukkan bahwa dalam Peraturan DPRD Nomor 1/DPRD/2014 tentang Tatib DPRD tersebut sangat kurang mengatur tentang naskah akademik. Hal ini tentunya tidak bersesuaian dengan peraturan yang lebih tinggi yakni UU Nomor 12 tahun 2011 tentang Pembentukan Peraturan Perundang-undangan dan Permendagri Nomor 1 Tahun 2014 tentang Pembentukan Produk Hukum Daerah. Dalam Undang-Undang Nomor 12 Tahun 2011 tentang Pembentukan Peraturan Perundang-undangan mewajibkan bahwa suatu rancangan peraturan perundang-undangan harus disertai dengan naskah akademik namun keberadaan naskah akademik menjadi hal yang penting atau sangat dibutuhkan dalam proses pembentukan rancangan Peraturan Daerah. Dimana dalam UU Nomor 12 tahun 2011 tentang Pembentukan Peraturan Perundang-undangan diatur secara jelas dan tegas tentang perihal naskah akademik, yaitu terdapat pada pasal 56 dan membagi rancangan Peraturan Daerah yang tidak harus disertai dengan naskah akademik dan yang harus disertai dengan naskah akademik.

Dalam Pasal 56 UU Nomor 12 Tahun 2011 tentang Pembentukan Peraturan Perundangundangan tersebut diatas sangat jauh berbeda dengan pengaturan terkait dengan naskah akademik dalam Peraturan DPRD Nomor 1/DPRD/2014 tentang Tatib DPRD Kabupaten Muna yang tidak mengatur secara jelas tentang penyertaan naskah akademik dalam suatu rancangan Perda. Dalam Permendagri Nomor 1 Tahun 2014 tentang Pembentukan Produk Hukum Daerah telah diatur pula secara rinci dan jelas terkait dengan naskah akademik. Hal ini dapat dilihat dari persiapan penyusunan rancangan Perda yang berasal dari pemerintah daerah yang diatur dalam dalam pasal 18, pasal 19, pasal 20 Permendagri Nomor 1 Tahun 2014 tentang Pembentukan Produk Hukum Daerah.

Dari hal tersebut diatas bahwa dalam peraturan DPRD Kabupaten Muna Nomor 1/DPRD/2014 tentang Tatib DPRD Kabupaten Muna tidak diatur secara rinci dan jelas terkait dengan naskah akademik sehingga hal tersebut tidak bersesuaian dengan UU Nomor 12 Tahun 2011 tentang Pembentukan Peraturan Perundang-undangan dan Permendagri Nomor 1 Tahun 2014 tentang Pembentukan Produk Hukum Daerah. Sehingga perlu adanya pengkajian ulang dan revisi khususnya yang berkaitan dengan adanya Prolegda dan naskah akademik agar dicantumkan dan diatur secara jelas kedalam pasal-pasal Peraturan DPRD tentang pembentukan peraturan daerah. Begitu pula terdapat materi yang sudah tidak sesuai lagi dengan lahirnya UU Nomor 12 Tahun 2011 tentang Pembentukan Peraturan Perundang-undangundangan dan Permendagri Nomor 12 Tahun 2014 Tentang Pembentukan Produk Hukum Daerah.

\section{Kendala-Kendala dalam Proses Pembentukan Peraturan Daerah Kabupaten Muna}

Secara umum kendala dalam pembentukan Peraturan Daerah di Kabupaten Muna dapat dibagi ke dalam 3 aspek atau bagian yaitu sebagai berikut:

1. Dari aspek substansi hukum

Dalam pembentukan peraturan daerah dikenal adanya program legislasi daerah dalam tahap perencanaan. Program legislasi daerah yang kemudian disebut dengan prolegda di lingkungan DPRD sampai saat ini belum memiliki pengaturan yang tegas dan jelas mengatur tentang rancangan Peraturan Daerah yang diajukan berdasarkan Prolegda. Dalam pasal 110 ayat 3 Peraturan DPRD Nomor 1/DPRD/2014 tentang Tatib DPRD tersebut hanya menjelaskan bahwa "Rancangan Peraturan Daerah disusun berdasarkan program legislasi daerah" tanpa mengatur secara rinci materi-materi yang dimasukkan dalam Prolegda dan pentingnya Prolegda. Berbeda dengan program legislasi nasional yang telah mempunyai pengaturan yang 
memadai mengenai substansi, prosedur penyusunan serta pengelolaannya. Tidak diaturnya secara rinci materi-materi yang dimasukan dalam Prolegda dan pentingnya Prolegda dalam peraturan DPRD No 1 tentang tata tertib DPRD ini menyebabkan program legislasi daerah oleh DPRD dianggap bukanlah sesuatu yang diharuskan dalam pembentukan peraturan daerah. Padahal secara tegas dalam pasal 39 Undang-Undang Nomor 12 tahun 2011 disebutkan bahwa perencanaan penyusunan peraturan daerah Kabupaten/Kota dilakukan dalam Prolegda Kabupaten/Kota.

Sebagaimana telah dikemukakan sebelumnya, adanya naskah akademik masih sangat minim dalam proses pembentukan perda di Kabupaten Muna. Hal ini dapat dilihat dari belum diaturnya secara tegas di dalam peraturan DPRD tentang pentingnya naskah akademik. Partisipasi masyarakat dalam pembuatan kebijakan publik, termasuk dalam pembuatan Perda menurut Sad Dian Utomo sesungguhnya dapat memberikan tiga manfaat, yaitu pertama jaminan landasan yang lebih baik; kedua, kepastian implementasi yang lebih efektif; ketiga, peningkatan kepercayaan masyarakat pada eksekutif dan legislative; keempat efisiensi sumber daya manusia. ${ }^{18}$ Naskah akademik harus menelaah 3 (tiga) permasalahan substansi, yaitu dapat menjawab pertanyaan mengapa diperlukan Perda baru, lingkup materi kandungan dan komponen utama Perda, dan proses yang akan digunakan untuk menyusun dan mengesahkan Perda. Ketiga hal tersebut merupakan hal-hal yang paling mendasar dalam proses pembentukan peraturan daerah. Selain itu, Naskah akademik memaparkan alasan-alasan, fakta atau latar belakang tentang hal-hal yang mendorong disusunnya suatu masalah sehingga dipandang sangat penting dan mendesak diatur dalam peraturan daerah. Manfaat dari data atau informasi yang dituangkan dalam latar belakang bagi pembentuk peraturan daerah itu, yakni bahwa para pihak pembentuk tersebut dapat mengetahui dengan pasti tentang mengapa perlu dibuat sebuah peraturan daerah dan apakah peraturan daerah tersebut memang diperlukan oleh masyarakat.

Pembentukan peraturan daerah di Kabupaten Muna harus membuat prolegda yang jelas dan terencana sehingga kepastian hukum dalam rangka tertib administrasi. Disamping itu, perlu adanya ketentuan yang lebih jelas dalam Peraturan DPRD Kabupaten Muna Nomor 1/DPRD/2014 tentang Tatib DPRD Kabupaten Muna bahwa dalam proses perencanaan suatu peraturan daerah harus memiliki naskah akademik. Mencermati kasus di kabupaten Muna, perlu adanya pengkajian ulang dan penggantian terhadap Peraturan DPRD Nomor 1/DPRD/2014 Tentang Tatib DPRD Kabupaten Muna agar tidak bertentangan dengan UU Nomor 12 Tahun 2011 Tentang Pembentukan Peraturan Perundang-undangan dan Peraturan Menteri Dalam Negeri Nomor 1 Tahun 2014 Tentang Pembentukan Produk Hukum Daerah.

Naskah akademik sendiri telah diatur pula dalam UU Nomor 12 Tahun 2011 sebagai pengganti UU Nomor 10 Tahun 2004. Banyak penambahan ketentuan yang terjadi dengan adanya undang-undang nomor 12 tahun 2011 ini, yakni salah satunya keharusan menyertakan naskah akademik dalam rancangan peraturan daerah yang diajukan atau disusun. Dengan melihat tujuan dari naskah akademik yakni untuk mendapatkan hasil pengkajian hukum terhadap sebuah materi muatan peraturan daerah, maka perlu adanya diskusi atau sosialisasi, seminar yang dilakukan oleh DPRD bersama dengan pemerintah daerah dengan melibatkan pihak akademisi atau perguruan tinggi dan lembaga swadaya masyarakat dan pihak-pihak terkait lainnya seperti kepolisian, kejaksaan. Hal ini dimaksudkan agar dapat menemukan suatu rumusan atau kajian hukum yang komprehensif terhadap suatu rancangan peraturan daerah yang akan dibentuk secara tepat dan bersifat bottom-up atau mencerminkan keinginan dari masyarakat luas. Selain itu, pihak DPRD harus segera merevisi aturan dari Tatib DPRD tentang pentingnya naskah akademik sehingga hal ini telah ditentukan secara pasti dan jelas di dalam

${ }^{18}$ Lihat Indra J Piliang, dkk, Otonomi Daerah: Evaluasi dan Proyeksi, (Jakarta: Yayasan Harkat Bangsa, 
Tatib DPRD Kabupaten Muna. Sebagai konsekwensinya bahwa sebelum membentuk suatu rancangan perda harus didasari lebih dulu dengan pembuatan naskah akademik.

\section{Dari aspek struktur hukum}

Dalam proses pembentukan peraturan daerah, sangat sedikit dari para pihak perancang atau pembentuk peraturan daerah yang memiliki pemahaman atas teori, metodologi, dan teknik perancangan peraturan perundang-undangan dan dapat secara jelas menerjemahkan kebijakankebijakan pemerintah menjadi peraturan daerah yang dapat dilaksanakan secara efektif. Akibat dari hal-hal tersebut, maka tidak mengherankan bila para perancang peraturan daerah baik pihak DPRD maupun dinas teknis (SKPD) yang mewakili bupati kembali pada kebiasaan yang bermasalah ketika merancang atau membentuk peraturan daerah, yaitu dengan menyadur atau mengcopy peraturan daerah lain berdasarkan kompromi keinginan dari kelompok-kelompok kepentingan dominan dalam masyarakat maupun DPRD serta SKPD itu sendiri. Selain itu, tidak dilibatkannya Perguruan Tinggi maupun pihak lain sehingga segala kekurangan dari para perancang tersebut baik dari pihak DPRD maupun pemerintah daerah tidak ada pihak yang dapat memberikan gambaran. Keterlibatan perguruan tinggi dalam proses pembentukan Perda sesungguhnya dapat menutupi kelemahan dari para perancang perda dari pihak DPRD dan SKPD.

Partisipasi dan pelibatan masyarakat dalam rancangan Perda adalah sebuah keniscayaan. Ia melekat erat dengan konsep demokrasi, sebagaimana dikemukakan oleh Philipus M. Hadjon yang disebut dengan demokrasi partisipasi yang muncul di tahun 1961. ${ }^{19}$ Dalam konsep ini rakyat mempunyai hak untuk ikut memutuskan dalam proses pengambilan keputusan pemerintahan. Akibatnya, partisipasi masyarakat kurang aktif dalam proses perencanaan, perancangan, pembahasan sampai pada tahap penetapan dan pengundangan perda dari anggota DPRD sehingga proses pembentukan suatu perda hanya bersifat formalitas dan prosedural belaka. Hal ini dapat dilihat dari kurangnya rancangan Perda yang diajukan oleh setiap anggota DPRD di tahun 2017 sebanyak 1 Raperda saja dari 5 perda yang ditetapkan dan diundangkan dalam lembaran daerah. ${ }^{20}$

Oleh sebab itu, perlu adanya pembinaan yang serius dan pelatihan terus menerus secara berkala kepada pemerintah daerah oleh SKPD maupun anggota DPRD, baik dilakukan di daerah maupun di Provinsi. Pematerinya bisa berasal dari pemerintah pusat yang berkompeten di bidang perancangan yang berupa teknik, metodologi penyusunan peraturan perundangundangan. Disamping itu, perlu adanya pembinaan terhadap kompetensi dari semua pihak baik dari bagian hukum, anggota DPRD, pimpinan DPRD dan SKPD sehingga akan ada peningkatan kualitas dari para pihak tersebut yang telibat dalam proses pembentukan suatu perda di Kabupaten Muna.

DPRD dalam hal ini merupakan fondasi atau penyangga masyarakat dan negara. Selain itu, perlu adanya staf ahli yang khusus ahli dibidang perancangan Perda, baik itu di DPRD maupun pemerintah daerah sehingga kendala-kendala dari SDM dapat diatasi dengan baik. Oleh sebab itu, perlu pula diadakan porsi anggaran lebih yang disediakan untuk pelatihan dan peningkatan kualitas SDM para per ancang baik dari pihak SKPD dan anggota DPRD, sehingga akan ada peningkatan terkait dengan teknik, metodologi pemebentukan peraturan daerah dari tahap perencanaan sampai pada tahap pengundangan.

\section{Dari aspek budaya hukum}

\footnotetext{
${ }^{19}$ Lihat Mahendra Putra Kurnia, dkk, Pedoman Naskah Akademik PERDA Partisipatif (Urgensi, Strategi, dan Proses Bagi Pembentukan Perda yang Baik), (Yogyakarta, Kreasi Total Media (KTM), 2007), hlm. 22.

${ }^{20}$ Data DPRD Kabupaten Muna, 2017
} 
Dalam proses pembentukan peraturan daerah, baik dimulai dari tahap perencanaan, perancangan, pembahasan, penetapan dan pengundangan sampai pada tahap sosialisasi, pemerintah daerah bersama dengan DPRD Kabupaten Muna masih cenderung menutup diri dari pihak luar, baik masyarakat maupun pihak akademisi. Padahal dalam pembentukan peraturan daerah peran serta dari masyarakat dan pihak akademisi sangat dibutuhkan untuk menghasilkan suatu peraturan daerah yang dikendaki oleh masyarakat luas. Ruang partisipasi masyarakat mestinya harus ada disetiap tahapan pembentukan peraturan daerah. Dengan demikian diharapkan akan lahir peraturan daerah yang partisipatif. Sebagaimana dijelaskan Ibnu Tricahyo bahwa negara selalu dipasangkan dengan warga negara dan dimana ada negara disitu selalu ada warga atau rakyat yang mengikutinya ${ }^{21}$, oleh sebab itu system ini harus terus berjalan dalam system pemerintahan. Maka sebagaiman ditegaskan Jazim Hamidi, bahwa dalam penyelenggaraan negara, negara (state) dan masyarakat tidak bisa dipisahkan secara parsial. $^{22}$

Pada dasarnya keikutsertaan dan partisipasi masyarakat didalam proses pembentukan peraturan daerah telah diatur oleh pasal 96 UU Nomor 12 tahun 2011 tentang pembentukan peraturan perundang-undangan. Ketentuan ini juga berarti dalam pembentukan suatu peraturan daerah harus terdapat prosedur yang memungkinkan masyarakat untuk berperan aktif didalam proses pembentukan peraturan daerah. Dalam tahap perencanaan dan perancangan peraturan daerah di DPRD Kabupaten Muna tidak didahului dengan penelitian untuk menemukan permasalahan apa yang harus dan dibentuk kedalam peraturan daerah. DPRD melalui anggotaanggotanya hanya mengamati dari luar saja masalah serta isu-isu yang berkembang dalam kondisi sosial masyarakat. Setelah itu pihak DPRD merumuskan sendiri peraturan seperti apa yang akan dihasilkan dengan disertai penjelasan atau keterangan sebagai dasar dalam membentuk peraturan daerah. Sejatinya, penelitian terhadap permasalahan yang muncul perlu dilakukan melalui cara-cara legal, seperti rapat dengar pendapat umum, kunjungan kerja, seminar, lokakarya atau diskusi dengan masyarakat langsung di lapangan untuk menemukan rumusan yang baik dalam merencanakan dan merancang suatu rancangan peraturan daerah.

Oleh sebab itu, ruang partisipasi masyarakat harus ada disetiap tahapan pembentukan peraturan daerah. Dengan demikian, diharapkan akan lahir peraturan daerah yang patisipatif. Adanya partisipasi dari masyarakat dapat dilihat dari adanya kesempatan untuk melakukan kajian terhadap rancangan Perda dan untuk memberikan masukan terkait rancangan Perda dan tanggapan terhadap masukan masyarakat dari keputusan atau ketetapan pemerintah daerah bersama dengan DPRD terkait suatu peraturan daerah. Untuk itu diharapkan DPRD bersamasama dengan pemerintah daerah dan unsur-unsur lainnya seperti kepolisian, LSM, akademisi, tokoh adat, tokoh agama dan tokoh kepemudaan dapat terlibat dalam melakukan sosialisasi atau diskusi dan kunjungan langsung ke tengah-tengah masyarakat sehingga aspirasi dari masyarakat dapat terserap dan didengarkan dan ditindaklanjuti. Selain itu, sosialisasi juga dpat dilakukan melalui jejaring sosial dan internet terkait dengan keinginan dan kebutuhan hukum dibentuknya suatu Raperda.

\section{Penutup}

Proses pembentukan peraturan daerah di Kabupaten Muna di dasarkan pada Peraturan DPRD Nomor 1/ DPRD/ 2014 Tentang Tata Tertib DPRD Kabupaten Muna yang diawali dari tahap perencanaan, penyusunan, pembahasan, penetapan, pengundangan, sosialisasi dan evaluasi peraturan daerah. Dalam prakteknya proses pembentukan peraturan daerah di

${ }^{21}$ Ibnu Tricahyo, “Urgensi Pengaturan tentang Pelayanan Publik”, Makalah tidak dipublikasikan, 2005, h. 1 .

${ }^{22}$ Jazim Hamidi, "Paradigma Baru Pembentukan dan Analisis Peraturan Daerah1 (Studi Atas Perda Pelayanan Publik dan Perda Keterbukaan Informasi Publik)”, Jurnal Hukum No. 3, Vol. 18 JULI 2011: 336 - 363. 
Kabupaten Muna hanya mengikuti tahapan prosedural saja tetapi tidak secara substansi diatur mengenai keharusan naskah akademik, adanya partisipasi masyarakat, program legislasi daerah yang secara rinci dan jelas di dalam Peraturan DPRD Nomor 1/DPRD/2014 Tentang Tata Tertib DPRD Kabupaten Muna. Hal tersebut tidak bersesuaian dengan UU Nomor 12 Tahun 2011 Tentang Pembentukan Peraturan Perundang-undangan dan Peraturan Menteri Dalam Negeri Nomor 1 Tahun 2014 tentang Pembentukan Produk Hukum Daerah. Dengan demikian, maka tidak seperti proses pembentukan Peraturan Derah pada wilayah lain di Indonesia, proses pembentukan Perda di Kabupaten Muna hanya bersifat formalitas dan praktis, dengan tidak mengindahkan prosedur hokum normative dan tanpa pelibatan masyarakat sebagaimana diatur dalam regulasi yang berlaku

Kendala-kendala yang dihadapi dalam proses pembentukan peraturan daerah di Kabupaten Muna, yaitu dari aspek substansi hukum tidak diaturnya secara jelas keharusan membuat naskah akademik dan Prolegda dalam Peraturan DPRD Nomor 1/DPRD/2014 tentang Tata Tertib DPRD Kabupaten Muna. Perlu adanya pelatihan kepada para perancang peraturan daerah baik dari pihak DPRD maupun dari pemerintah daerah. Dari aspek struktur hukum yaitu kurangnya sumber daya manusia dari pihak DPRD maupun pemerintah daerah. Maka, perlu ada pengkajian ulang terhadap Peraturan DPRD Nomor 1/DPRD/2014 Tentang Tata Tertib DPRD Kabupaten Muna. Dari aspek budaya hukum yaitu kurangnya partisipasi dan ruang bagi masyarakat, perguruan tinggi serta pihak lain terkait adanya sosialisasi langsung maupun melalui media cetak dan elektronik dalam proses pembentukan peraturan daerah. Maka perlu dibukanya ruang partisipasi aktif masyarakat melalui sosialisasi langsung, media cetak dan elektronik.

\section{Daftar Pustaka}

Asshiddiqie, Jimly. Konstitusi dan Konstitualisme Indonesia. Jakarta: Konstitusi Press, 2006.

Chandraningrum, Dewi. "Perda Sharia and the Indonesian Women's Critical Perspectives', Paper presented to Perda Syariah (New Arbitrary against Women in Indonesia: Perda Sharia and Women's Right, Bremen, Germany, 11 November 2006.

Danusastro, Sunarno. Penyusunan Program Legislasi Daerah yang Partisipatif, Jurnal Konstitusi, Volume 9, Nomor 4, Desember 2012: 642-660.

Fauzan, Muhammad. Hukum Pemerintahan Daerah Kajian Tentang Hubungan Keuangan Antara Pusat dan Daerah. Yogyakarta: UII Press, 2006.

Hamidi, Jazim. "Paradigma Baru Pembentukan dan Analisis Peraturan Daerah1 (Studi Atas Perda Pelayanan Publik dan Perda Keterbukaan Informasi Publik)". Jurnal Hukum No. 3, Vol. 18 Juli 2011: 336-363.

Huda, Ni’Matul. Hukum Pemerintahan Daerah. Bandung: Nusa Media, 2009.

Ibrahim, Anis. "Legislasi Dalam Perspektif Demokrasi: Analisis Interaksi Politik Dan Hukum Dalam Proses Pembentukan Peraturan Daerah Di Jawa Timur", Disertasi di Uniersitas Diponegoro Semarang, 2008.

Kurnia, Mahendra Putra, dkk, Pedoman Naskah Skademik PERDA Partisipatif (Urgensi, Strategi, dan Proses Bagi Pembentukan Perda yang Baik), (Yogyakarta, Kreasi Total Media (KTM), 2007). 
Marpaung, Heri Wahyudi. "Implementasi Peraturan Daerah Kabupaten Labuhanbatu Nomor 37 Tahun 2008 Tentang Pembentukan Organisasi Dan Tata Kerja Kecamatan”, Jurnal Administrasi Publik, Vol. 1, No. 1, Juni 2011: 29-50.

Mertokusumo, Sudikno. Mengenal Hukum Suatu Pengantar. Yogyakarta: Liberty, 1996.

Mutik, Kemilau. "Kedudukan Naskah Akademik Dalam Proses Pembentukan Peraturan Daerah”. Tesis di Fakultas Hukum Universitas Brawijaya, Malang, 2010.

Piliang, Indra J, dkk. Otonomi Daerah: Evaluasi dan Proyeksi. Jakarta: Yayasan Harkat Bangsa, 2003.

Ratu, Frederick Afridus dan Argo Pambudi, Implementasi Perda No. 6 Tahun 2015 Tentang Perparkiran Di Kabupaten Sleman. Yogyakarta: Universitas Negeri Yogyakarta, 2016.

Saragih, Tomy M. "Konsep Partisipasi Masyarakat Dalam Pembentukan Peraturan Daerah Rencana Detail Tata Ruang Dan Kawasan”, Jurnal Sasi Vol. 17 No. 3 Bulan JuliSeptember 2011: 11-20.

Setyadi, Bambang. "Pembentukan Peraturan Daerah", Buletin Hukum Perbankan Dan Kebanksentralan, Volume 5, Nomor 2, Agustus 2007: 1-17.

Tricahyo, Ibnu "Urgensi Pengaturan tentang Pelayanan Publik", Makalah tidak dipublikasikan, 2005.

\section{Undang-Undang;}

Undang-Undang Negara Republik Indonesia Nomor 12 Tahun 2011 Tentang Pembentukan Peraturan Perundang-undangan.

Undang-Undang Negara Republik Indonesia Nomor 23 Tahun 2014 Tentang Pemerintahan Daerah.

Peraturan Menteri Dalam Negeri Nomor 1 Tahun 2014 Tentang Pembentukan Produk Hukum Daerah

Peraturan Dewan Perwakilan Rakyat Daerah Kabupaten Muna Nomor 1/ DPRD/ 2014 tentang Tata Tertib Dewan Perwakilan Rakyat Kabupaten Muna. 